\title{
Hvorfor Bjørnstjerne Bjørnson døde i Paris i 1910
}

I 2010 er det 100 år siden Bjørnstjerne Bjørnson (1832-1910) døde. I 1995 beskrev nevrolog Johan A. Aarli (f. 1936) hvorfor Bjørnson døde i Paris (Tidsskr Nor Lægeforen 1995; 115: 3740 -4). Dikteren ønsket å få elektroterapi av den franske legen Jaques Arsène d'Arsonval (1851-1940). Hans trofaste lege hjemme i Gausdal, Carl Mathiesen (1861-1952), fulgte med på den siste reisen.

\section{Medisinsk behandling i utlandet}

Han hadde vært plaget av angina pectoris i en tid, og hadde en lidelse som var oppfattet som tromboflebitt i høyre bein. Våren 1909 bodde han i Paris og fikk da behandling i elektrisk kammer hos d'Arsonval, en terapi som var meget populær rundt århundreskiftet. Da han kom hjem til Norge, i mai 1909, fikk han et vaskulært insult, ble lam i venstre side, sannsynligvis på grunn av en høyresidig carotistrombose, og fikk også en fokal epilepsi. Han hadde alltid vært en aktiv, rastløs person, og dette satte ham utenfor på en måte som han ikke klarte å forsone seg med. Han bestemte seg da for å dra tilbake til Paris for på ny å få elektroterapi. Han ble fraktet med den danske konges private jernbanevogn og ble mottatt som den franske republikks gjest. Han tok inn på Hotel Wagram hvor utstyret for elektroterapi ble installert, og han fikk sin behandling, men hans helse ble gradvis svekket, og han døde i april 1910. 